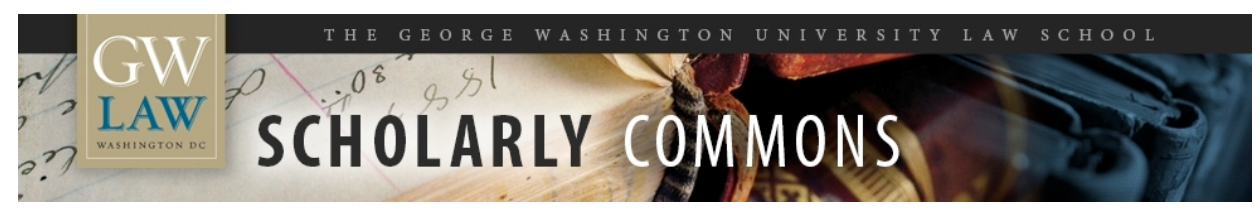

GW Law Faculty Publications \& Other Works

Faculty Scholarship

2003

\title{
Empirical Research Into the Chinese Judicial System
}

Donald C. Clarke

George Washington University Law School, dclarke@law.gwu.edu

Follow this and additional works at: https://scholarship.law.gwu.edu/faculty_publications

Part of the Law Commons

\section{Recommended Citation}

Beyond Common Knowledge: Empirical Approaches to the Rule of Law 164 (Erik G. Jensen \& Thomas C. Heller eds., 2003)

This Book Part is brought to you for free and open access by the Faculty Scholarship at Scholarly Commons. It has been accepted for inclusion in GW Law Faculty Publications \& Other Works by an authorized administrator of Scholarly Commons. For more information, please contact spagel@law.gwu.edu. 


\section{Beyond Common Knowledge}

Empirical Approaches to the Rule of Law

EDITED BY ERIK G. JENSEN AND THOMAS C. HELLER

Stanford Law and Politics An imprint of Stanford University Press Stanford, California

2003 
The Ford Foundation, for example, through its funding of the Committee on Legal Education Exchange with China, sponsored the legal education in the United States of numerous Chinese scholars in the I980s and I990s. In the early I990s, the foundation became involved with legal-aid and publicinterest law programs and recently has supported WTO-related projects. ${ }^{3}$ One of the main components of its law-related work in China has been its judicial reform initiative, which consists of legal research, trial reforms, training, and professionalization. ${ }^{4}$

This list of projects is undoubtedly incomplete, but it does show that there is a great deal of interest and activity on the part of international funding agencies in projects designed to enhance the quality of China's legal system. What is not clear, however, is whether there has been systematic thinking about the goals of these and other projects, whether those goals are appropriate, and indeed whether their achievement can be ascertained in some measurable way.

This paper is an attempt to think about what we know, what we might THE LAST FEW YEARS have seen a proliferation of programs by Western states and international agencies designed, in broad terms, to promote reforms in the Chinese judicial system. Many of these programs have been related to China's imminent entry into the World Trade Organization (WTO). The European Union, for example, launched a WTO-related legal assistance program in March 2000. Australia has been operating a graduate certificate training program for Chinese officials selected by the Ministry of Foreign Trade and Economic Cooperation (MOFTEC) at the University of Adelaide for several years. Germany has an advisory project in commercial law with the National People's Congress that relates to WTO standards and regulations. ${ }^{1}$ In addition, it has an extensive training program with MOFTEC's Treaties and Law Department to provide advice and shorter-term training to officials at MOFTEC and its local-government counterparts, as well as to state-owned enterprise legal departments. The Germans also have been involved in training Chinese judges. Canada conducted a now-completed multiyear project training Chinese officials in WTO terminology and processes to help prepare them for bilateral and multilateral accession negotiations. Other WTO-related projects include work with the Ministry of Information Industry on developing an Internet policy framework, and an industrial and trade policy initiative in the automotive sector. Canada also is working with the Ministry of Agriculture and the State Development Planning Commission (SDPC) on an inventory of national and subnational agricultural laws, regulations, and policies that are inconsistent with WTO disciplines.

Although the U.S. government has until recently been conspicuously absent from the list of countries engaging in law-related projects, private foundations have been involved in projects of various kinds (see DeLisle 1999). ${ }^{2}$ want to know, and what we can know about China's judicial system broadly defined. I say "broadly defined" because one of the pitfalls of legal-reform projects is defining the object of reform too narrowly on the basis of assumptions that would be better seen as hypotheses needing proof. For example, reform efforts directed at courts have as their unstated premise the notion that courts are important in the Chinese legal system; indeed, government reform efforts directed at the legal system have as their unstated premise the notion that the legal system is important in the Chinese polity. These propositions might or might not be true; and even if they are not true, a decision might be made to pursue the project in any case. But it is important at least to examine them in order to avoid spending resources on an effort of only marginal importance while neglecting areas where a much greater return might be expected.

\section{Sources of Data on the Chinese Legal System}

What we already know, in the form of reliable data, about the Chinese legal system is not much. ${ }^{5}$ Useful data are generally not available, and the available data are not very useful. This is not necessarily because Chinese and foreign scholars are not interested in empirical data or field research. Chenguang Wang (1998) has published an interesting article on court efficiency, but his comparison of the United States and China shows only how unsatisfactory the available data are on China. Weifang $\mathrm{He}$ (I998) has shown a consistent interest in the actual operation of China's judicial institutions, and the Ford Foundation in the mid-I9gos sponsored field research into the operation of China's court system in the countryside. ${ }^{6}$ But that research was 
not intended to yield — and did not yield - hard statistics about the judicial system.

A prime source of data on the judicial system is the annual China Law Yearbook (CLY) (Zhongguo Falï Nianjian). Although the CLY is not officially published by a government organization such as the Supreme People's Court (SPC) or the National People's Congress (NPC), it shares editors with a number of official law-related bodies and can be considered authoritative. The CLY publishes several tables of statistics about the judicial system, but for the most part the statistics relate only to the numbers and types of cases handled by various institutions such as the courts, the procuracy, and the police. The $C L Y$ provides no systematic information on personnel and finances. ${ }^{7}$

Other yearbooks - general, topical, and local-can be useful sources of statistics. ${ }^{8}$ The Yearbook of People's Courts (Renmin Fayuan Nianjian) reported information about courts and the Chinese legal system during its brief life span, but it has not been published since r99r.

From time to time, various statistics can be gleaned from official speeches and reports. The presidents of the SPC and the Supreme People's Procuracy report on the work of their respective institutions to the annual meetings of the NPC. Like the CLY, these reports typically present large quantities of statistics, but not many of them are helpful. The SPC report typically indicates the number of cases of various kinds handled by the courts, and the percentage change from the previous year. Although these data might be useful for certain limited purposes, as we show below, they tell us much less than we think:

Academic articles as well as newspaper reports often contain snippets of measurable data about the institutions and personnel of the judicial system, but they rarely cite the sources of their information. ${ }^{9}$ My own inquiries of Chinese colleagues reveal that in many cases the sources of information for Chinese academics are no better than those available to Western scholars. ${ }^{10}$ Although occasionally numbers show up that appear to be hard data, their provenance is difficult to ascertain, and it is not always clear that the author is using them appropriately. For example, Xiaobin Li (r998, 53) asserts that in 1997 there were 270,000 "judges" (faguan) in the court system, and that they completed hearings of an average of twenty-one cases per person that year. However, other sources make it clear that $\mathrm{Li}$ is really talking about all officials in the courts with cadre status, including, for example, court police ( fajing), for whom other authors cite figures of 250,000 for 1997 (Tan 200I) and 280,000 for I998 (Zhang and Wu 2000, 56). Had Li counted judges at the more likely number of 170,000 (Tan 200I), he would have arrived at an average of thirty-three cases per judge.
The best sources for these occasional pieces of information, in addition to the official gazettes of the SPC and the Supreme People's Procuracy, probably are the journal People's Judicature (Renmin Sifa) and the newspaper People's Court News (Renmin Fayuan Bao). Both are published under the auspices of the courts and have much less of a theoretical bent than the academic journals. Some local courts, such as the Shandong Higher-Level People's Court and the Haidian Basic-Level People's Court in Beijing, publish their own journals. These can be good sources for insight into the actual workings of the judicial system, although they have no better grasp of the national picture than do other sources.

There are a number of case collections, of which the most prominent, published by the People's Court Press, is an annual series called the Selected Important Trial Cases of China (Zhongguo Shenpan Anli Yaolan). The press also issues a series titled Selected Cases from People's Courts (Renmin Fayuan Anli Xuan). The difficulty with these collections as sources of data is that the cases are not chosen randomly, and so cannot be used to make descriptive inferences about a larger population of cases. ${ }^{11}$ Unfortunately, we do not yet have good information on the process by which the cases come to the attention of the editors and are then selected.

Finally, of course, one important source of data is original research. For all scholars, foreign and Chinese (who might be thought to have a home court advantage), obtaining valuable and representative data is very difficult. ${ }^{12}$ But it is not impossible, as Peerenboom's (20orb) study on the enforcement by Chinese courts of arbitration awards shows. Survey research has also been conducted in the area generally described by the term "legal culture," 13 although no conclusions about changes in attitudes can be drawn from a survey of attitudes at a given point in time. The operation of the administrative law system has been of particular interest to fieldwork-oriented Chinese scholars, and at least two interesting collections of studies have appeared (Jiang I998; Ying and Yuan 200I).

By piecing together information from all of these sources, Chinese and foreign scholars have been able to assemble a picture of certain aspects of the Chinese legal system. That picture is by no means complete. But fleshing it out requires a great deal of thought about what information needs to be gathered and how it can be gathered effectively.

\section{Empirical Research: The Issues}

The first question is Does it make sense to look at China's judicial system at all, even broadly defined? Of course no research into a particular institution or set of institutions makes sense without an animating purpose, so this question 
cannot be answered in the abstract. It is worth considering, however, because in many cases the purpose behind the research may not be served by an investigation into China's judicial institutions. Suppose, for example, that the purpose of our research is to learn about the institutions that make final decisions about the rules governing relations between the central and local governments in China. If we simply apply an American model, we would naturally investigate Chinese judicial institutions. But in China, that investigation would yield nothing of value relating to the purpose of the inquiry. Although this example might seem obvious, there are other cases in which the inapplicability of the basic assumptions will be far less obvious.

Assuming, however, that the legal system, broadly defined, is indeed the appropriate subject of inquiry, the next question is Which institutions in the legal system should be studied? Here the possibilities of misapplying a foreign model are even greater. In particular, it is highly tempting for those with Western (and especially common law) legal training to assume that courts are the appropriate focus of a study of legal institutions. Courts, after all, produce the opinions that we study in law school, and in common law jurisdictions in particular they are very powerful. It is impossible to provide a full account of a Western legal system without devoting substantial space to the courts. On the other hand, a book about the Chinese legal system. with the chapter on the courts torn out would still be a very useful book. Indeed, until quite recently, that chapter would have been quite short and hardly missed at all. ${ }^{14}$

Thus, a full understanding of the important aspects of the Chinese legal system must not stop with an empirical investigation of the functioning of courts. As one Chinese academic remarked to me, "Law's empire has many capitals." 15 In addition to the courts, there are a number of other legal institutions in China that warrant investigation but tend to be overlooked.

\section{THE PROCURACY}

The Supreme People's Procuracy (Zuigao Renmin Jianchayuan) is formally a coequal branch of government with the Supreme People's Court, the State Council, and the Military Affairs Commission. ${ }^{16}$ Its head, like the heads of the other branches, is appointed directly by the NPC. Based on the Soviet procuracy, its main function is the investigation of crimes committed by state officials in the course of their duties and the prosecution of most criminal cases, but it has other responsibilities as well, including the supervision of the legality of government work in general and of the activities of officials in other legal institutions (such as the police, the prisons, and the courts). ${ }^{17}$

With a few exceptions, ${ }^{18}$ neither Western nor Chinese legal scholars have studied the procuracy extensively, presumably because of customary ideas about the subject matter of legal scholarship. Yet the procuracy may well have an important role in the Chinese legal system, one that is as important as that of the courts. ${ }^{19}$ This seems especially likely given the very high rates of convictions in criminal cases; evidently important determinations are being made before cases ever get to the courts.

\section{LEGAL AFFAIRS OFFICES}

Another institution worth study is the legal affairs office ( fazhi bangongshi) set up at each level of local government. These offices are the counterparts of the State Council's Legal Affairs Office, but they seem to play a somewhat different role. The State Council, under the premier, manages the day-to-day functioning of China's central government-it operates as the executive branch of the government. The Legal Affairs Office is charged with overseeing the drafting of laws for which the State Council is responsible. Those laws include bills destined for passage by the NPC as well as rules the State Council or its ministries have authority to promulgate themselves. ${ }^{20}$

According to one group of academics with whom I spoke (Interview 200I), local legal affairs offices are often delegated the task of deciding administrative appeals ( $x$ ingzheng fuyi), and their personnel have a greater level of legal sophistication than do those in other government departments. If local governments tend to delegate hearings (or the final stages of hearings) of administrative appeals to local legal affairs office, and if their personnel are relatively knowledgeable about legal matters, then it is reasonable to look on them as a quasi-judicial institution and to investigate them accordingly.

By the same token, it. would be worth studying the local equivalents of the National People's Congress's Legal Affairs Commission (Falü Gongzuo Weiyuanhui). These bodies, often (and confusingly) called legal affairs offices at the local level, apparently have a great deal of authority in setting agendas and drafting legislation (Interview 200I).

\section{LEGAL SERVICES}

A crucial part of any legal system is the delivery of legal services to individuals. Yet we understand very little of how this is accomplished-or not accomplished-in China. Here, useful research should be possible because the government does not consider information about the legal profession to be especially sensitive. To paint a general picture about the accessibility of legal services and to measure meaningful changes, information is needed about fee structures, education level, number of attorneys, geographic distribution, and the types of cases handled.

However, it is crucial in this type of research to understand what it is that the providers of what we assume to be legal services are actually doing before we draw conclusions about the legal system. If willing buyers are pay- 
ing lawyers to help them win lawsuits in court, this indicates that a court judgment in one's favor is something of value. But if the lawyers are providing value to their clients by taking officials out to nightclubs, then a different conclusion about the legal system must be drawn.

At the moment, only some very basic information about lawyers is available; and very little is known about the financial structure and internal workings of law firms. According to $\mathrm{Gu}(1999,52)$, there were 80,000 full-time lawyers and 20,000 part-time lawyers in China at the end of 1998. Hongwei Shen $(2000,8 \mathrm{I})$ states that there were $\mathrm{I}$ I0,000 lawyers in 2000.

A key question here has to do with the qualifications of those called lawyers. Of the I I0, ooo lawyers Hongwei Shen found, only about 60,000 had passed the bar exam (8I). ${ }^{21}$ The implication, of course, is that about 50,000 had not passed the bar exam. These people have become lawyers through other means, such as grandfathering. Moreover, by the end of 1996 , only one-quarter of those with a lawyer qualification had an undergraduate degree in any subject (Weili Zhang 1997).

\section{MEDIATION AND ARBITRATION}

Mediation involves the efforts of a third party (mediator) to bring the disputing parties to a voluntary agreement. In arbitration, the disputing parties choose a third party (arbitrator) and agree before the process begins that the arbitrator's decision will be binding on them and enforceable in court. (In adjudication, of course, the parties do not have the right to reject either the decision or the decision maker.) Both/mediation and arbitration deserve special attention within the Chinese legal system because of their semiofficial status.

The state has established specialized institutions for mediation-people's mediation committees (renmin tiaojie weiyuanhui) and judicial assistants (sifa zhuliyuan) - and quite purposefully uses those institutions to inculcate state norms. Mediation merely to reach an agreement satisfactory to the parties is condemned as "unprincipled." Moreover, there is ample evidence that mediation in China often carries a degree of coercion. Given the importance of state norms to the process and the coercion in the process, combined with the reluctance of the courts to hear minor cases, mediation in many cases seems more like adjudication - a kind of small-claims proceeding - than a form of alternative dispute resolution. ${ }^{22}$

Mediation seems to have been steadily declining in importance in recent years: the number of officially mediated disputes fell from just over 6 million to just over $S$ million from I995 to 1999 (Falii Nianjian 2000, I226). But even the latter number is well above the number of civil cases accepted by courts - 3.5 million - in the same year (I210)

Arbitration is also important because of the close connection between its institutions and the state and its norms. This connection goes beyond the need to resort to courts for the enforcement of an arbitration award against a recalcitrant defendant. In China, arbitration awards generally are enforceable only if issued by a state-recognized arbitral body. With the exception of international arbitration, the disputing parties usually do not have the right to choose whomever they please as an arbitrator. ${ }^{23}$ And underscoring the semiofficial status of arbitration in China, state-recognized arbitral bodies can change their jurisdiction without a change in "state" law. ${ }^{24}$ Their internal rules may even purport to confer jurisdiction on the courts with respect to certain matters. ${ }^{25}$

Local arbitration commissions are closely tied to government in a number of ways: they rely on local government for their funding and for personnel..$^{26}$ All of this is simply to show that it would be a mistake to be misled by the word "arbitration" into thinking that so-called arbitration institutions are not a key part of the official legal system. ${ }^{27}$

Finally, both mediation and arbitration have a direct bearing on the legal system because even where the rules do not mandate alternative dispute resolution, it appears that the courts as a matter of practice often do require that parties attempt mediation or arbitration before they accept a case for adjudication. $^{28}$

\section{THE COURTS}

Although the courts seem an obvious subject for investigation in any study of a legal system, it is important to investigate the right things. ${ }^{29}$ The point of doing research on an institution is to see how the institution measures up in some respect that we think is important. We don't gather information on the average height of judges because we doubt it affects anything courts do that we consider important - for example, delivering justice. It is crucial that we be able to justify why we are measuring the thing we are measuring. Any justification we make is going to depend on some model, explicit or implicit, of how courts ought to function and what role they ought to be playing. Therefore, if we see Chinese courts as properly functioning in the way Western courts do, we will be interested in measuring their capacity to do the things Western courts and judges do. This approach might yield results, but the results could well be of marginal importance. Perhaps Chinese courts are not designed to do, and should not do, the things Western courts do.

Take a cardinal rule of the U.S. courts: the courts should be passive and should wait for parties to bring cases to them. ${ }^{30}$ The parties activate judicial machinery at their option; that is in the basic nature of a right. But courts in China are not necessarily intended to function the same way. One could see them, for example, as part of a state-building project, a means for the 
central government to assert its authority down to the grass roots ( $\mathrm{Su} 2000 \mathrm{~b}$ ). In such a model, courts and court officials are not supposed to wait passively for cases to come before them. They have a larger, more complex role to play. We may misunderstand a key feature of courts' functioning if we measure their activity using indices designed for institutions with a different mission. ${ }^{31}$

Any study of what the Chinese courts do, then, should include a study of the docketing (li'an) system whereby the courts decide which cases to hear. This has no parallel in common law trial courts because those courts do not get to decide: they must take all of the cases that come before them. Chinese courts, however, can decide, not only to refuse a case that has come before them, but also to undertake a case that has not come before them by way of a party's complaint. In this environment, understanding something about the types of cases the courts seek out, as well as the proportion of those cases relative to other cases, could be very instructive.

A second, equally important element in a study of the courts in China would be understanding the relative importance of the various activities the courts carry out. Although it is commonly said that courts exist primarily to decide disputes, ${ }^{32}$ whether this is true in China is a matter for empirical research, not a priori definitional fiat. How to weigh the different activities of courts against one another is, of course, a difficult question. Do we look at person-hours, for example? Or expenditures? But we cannot take for granted that the main purpose of courts is to resolve disputes, any more than we can assume that was the main purpose of the yamen in imperial China. ${ }^{33}$ To look solely at the dispute resolution capacity of the courts might be to overlook some other important role they play - or are wanted by some to play - in Chinese society.

The future role of the courts in China is a topic of sharp debate. Many, particularly legal academics, believe that the courts should be strengthened to the point where they can be a meaningful check on government action. This opens another avenue of study: the courts' capacity to resolve disputes may be much less important than their potential to legitimate the actions of the state. Increasingly the Chinese state refers to an ideology of legality (as opposed, for example, to an ideology of revolutionary Marxism) as a basis for its legitimacy. ${ }^{34}$ And Chinese courts, despite their low-status origins, have enjoyed an instant promotion because of their automatic inclusion in the ranks of important legal institutions. ${ }^{35}$ As their symbolic importance grows, measurements aimed at their ostensible functions become less meaningful and less useful in understanding them. Thurman Arnold (r935) argued, for example, that given the strictures of the rules of evidence, the idiosyncratic definitions of criminal responsibility, and the lack of connection between criminal sentences and social purpose, "the only function which the criminal trial can perform is to express currently held ideals about crime and about trials" (I47-48). ${ }^{36}$ Imaginative hypotheses about the symbolic role of the courts in Chinese society might well generate consideration of data hitherto ignored.

By the same token, data we might normally collect may not be helpful. Key to understanding Chinese courts, for example, is understanding that they are essentially a bureaucracy, like other bureaucracies in the Chinese government. This means they are often called on to do the kinds of tasks Chinese bureaucracies are often called on to do-for example, to help with the latest birth control campaign or tax collection drive (see Haijian $\mathrm{He}$ 1993). They do not occupy (except formally) a position apart from and superior to the rest of the government. Consequently, we should attempt to measure their performance using the measures we would apply to other Chinese government bureaucracies; attempts to apply measures we would apply to courts in the United States are likely to fail.

Number of Personnel. Take an apparently simple statistic: the number of judges. This information is of interest because it presumably bears on the capacity of the courts to hear a certain number of cases. The number of judges can affect the number of cases heard, the time to disposition, and possibly the quality of the judgments. But in the Chinese context, the question of the number of judges becomes almost impossible to answer in a meaningful way. Because Chinese courts operate as bureaucratic offices, the relevant statistical categories in China are state cadres versus nonstate cadres, and rank within the office. ${ }^{37}$ Statistics on court personnel, then, scarce to begin with, tend to lump together-under the general term "ganjing"- everyone with the rank of state cadre, including judges, clerks, court police, and even drivers. ${ }^{38}$ Authors who cite numbers for judges are often referring to the numbers for cadres and so overstate the number of people who actually hear cases. $^{39}$

The data in Table S.I illustrate the problem. ${ }^{40}$ Consider the data for 1997. The Falü Nianjian (1998) reported 270,000-plus "persons," I70,000-plus of them judges ( $f a g u a n)$; Xiaobin Li (1998) reported 270,000 judges. By examining numbers from other sources, a general picture emerges that supports the data in the Falü Nianjian: by the end of 1997 , there were I70,000 people employed in the courts who were formally eligible to hear and decide cases, and another 100,000 people with state-cadre status who performed other tasks. Those who give a higher number in any given year for "judges" are simply wrong.

There are discrepancies in other categories in Table S.I, too. For example, adjudication personnel (shenpan renyuan) are not necessarily involved in adjudication: among the staff in this category are administrative officials, 
TABLE S.I

Court Personnel in China, Selected Years, 1979-1998

\begin{tabular}{|c|c|c|c|}
\hline Year* & Number & Category & Source \\
\hline 1979 & 59,000 & Cadres and police (ganjing) & Zhang and Wu $(2000,56)$ \\
\hline & & Persons & Falü Nianjian $(1998,71)$ \\
\hline .1986 & 147,283 & $\begin{array}{l}\text { Court president; court vice } \\
\text { president; adjudication personnel } \\
\text { (shenpan renyuan), including } \\
\text { assistant adjudication personnel, } \\
\text { clerks, and execution personnel }\end{array}$ & Falü Nianjian $(1988,883$, table 2$)$ \\
\hline & 15,203 & Other ganjing (cadres and police) & Falï Nianjian $(1988,883$, table 2$)$ \\
\hline \multirow[t]{3}{*}{1991} & 138,459 & Judges & U.S. Department of Justice (n.d.) \\
\hline & 138,459 & $\begin{array}{l}\text { Assistant adjudication personnel } \\
\text { (zhuli shenpan renyuan) and above } \\
\text { (including court presidents and } \\
\text { vice presidents) }\end{array}$ & Chenguang Wang $(1998,50)$ \\
\hline & 61,675 & Clerks (shuji yuan) and court police & Chenguang Wang $(1998,50)$ \\
\hline 1992 & 140,000 & $\begin{array}{l}\text { Adjudication personnel } \\
\text { (shenpan renyuan) }\end{array}$ & $\operatorname{Tan}(2001)$ \\
\hline 1996 & 250,000 & Judges ( faguan) & Liming Wang $(2000,420)$ \\
\hline \multirow[t]{4}{*}{1997} & 170,000 & $\begin{array}{l}\text { Adjudication personnel } \\
{\text { (shenpan renyuan })^{\dagger}}^{\dagger}\end{array}$ & Tan (2001) \\
\hline & $\begin{array}{l}170,000^{\dagger} \\
270,000^{\dagger}\end{array}$ & $\begin{array}{l}\text { Judges ( faguan) } \\
\text { Persons }\end{array}$ & Falü Nianjian $(1998,71)$ \\
\hline & 250,000 & Cadres (ganbu) & $\operatorname{Tan}(2001)$ \\
\hline & 270,000 & Judges (faguan) & Xiaobin Li $(1998,53)$ \\
\hline \multirow[t]{2}{*}{1998} & 170,000 & Judges (faguan) & Cui and Yang (2001) \\
\hline & 280,000 & Cadres and police (ganjing) & Zhang and Wu $(2000,56)$ \\
\hline
\end{tabular}

*Figures are at year's end.

tDoes not include clerks, court police, or other cadres.

such as court presidents and vice presidents, who generally do not hear cases, and those responsible for the execution of judgments. Xiaobin Li (I998), in his study of nine Basic-Level People's Courts (BLPCs), found that only 44 percent of the 762 people labeled "judges" actually heard cases. Another 44 percent were the presidents, vice presidents, heads of chamber, and deputy heads of chamber, and rarely or never heard cases. The remaining I2 percent occupied positions in various court departments, such as the political work department, the secretariat, the labor union, the administrative office, the archives department, the accounting department, and the department in charge of the execution of judgments. According to Tan (200r), Higher-Level People's Courts (HLPCs), at the province level, typically have 200 to 300 "judges," few of whom actually hear cases.

Even those who do hear cases may also be engaged in a great deal of other, unrelated work. The mobilization of court personnel by local governments to perform various public chores is a frequent source of complaint in the legal literature. According to Liming Wang (2000, 42 I), local govern- ments often enlist judges in the work of birth control, tax collecting, urban beautification, and the physical expulsion of beggars. ${ }^{41}$

The problem does not end with statistics that are overinclusive. Some of these data may be considerably underinclusive. If by "judges" we mean people who hear cases, then the numbers should include people's assessors (renmin peishenyuan). ${ }^{42}$ In many courts, it seems that the people's assessor system is a dead letter. ${ }^{43}$ In other courts, however, the people's assessors have in effect become long-term employees, typically paid out of extrabudgetary funds garnered through litigation fees. The normal length of service for assessors is two years, but, according to Jiahong $\mathrm{He}$ (1999, I3), in some cases stretches out to ten to twenty years. If that is so, then probably the assessors are functioning in every essential respect as judges and should be counted if we are attempting to understand the number of people available to hear cases. ${ }^{44}$ Unfortunately, the recordkeeping branches of the Supreme People's Court probably do not know how many people are working for local courts and being paid from extrabudgetary funds (Interview 200I).

Again, the key distinction here is not whether an individual hears cases or not, but whether the individual is a cadre or a worker. ${ }^{45}$ Because clerks and judicial police are cadres, it is possible for them to be promoted within their work unit (the court), which means they can become judges (Interview 200I). In addition, those with cadre status may be pressed into service as judges when manpower is low, without being formally promoted (Liming Wang 2000; and see Xiaobin Li 1998). Because the court is a typical Chinese work unit, for a driver to become a judge is no stranger than a mailroom clerk's rising through the ranks to become a corporate executive.

These characteristics of the courts have definite implications for research They mean, for example, that it is not enough for us to know that courts have judges; we must also determine the bureaucratic rank of judges. Xiaobin $\mathrm{Li}$ $(1998,53)$ asserted that in 1998 , "the center" issued a document stating that adjudication personnel (shenpanyuan) should have the status of $k e-$ level cadres. ${ }^{46}$ Apparently this reform has not been implemented thoroughly, or perhaps at all; according to $\mathrm{Li}$, judges make less money than court police. ${ }^{47}$ In any case, bureaucratic rank of the typical officeholder can be seen as a reasonably accurate indicator of the relative importance in the Chinese polity of a particular government post, and it would tell us something useful about the courts to observe changes in the bureaucratic rank of court cadres over time, without worrying about whether they should count as judges or not.

Education. As Edmund Burke (I790/1982) noted long ago, understanding the characteristics of those who staff an institution "is of ten thousand times greater consequence than all the formalities in the world" (I27). Yet we know very little about the characteristics of Chinese judges. One area of 
interest to researchers, but as fraught with pitfalls as that of judicial numbers, is judicial education and training.

Judges traditionally have not been required to have any special training or educational qualifications before coming to office. Standards for new judges were raised with the passage of the Law on Judges in 1994. And since March 2002 , prospective judges, lawyers, and procurators all have been required to pass the same examination. Training of judges has typically been done on the job. In I985, for example, the SPC established the Court Cadres Part-Time Law University (Fayuan Ganbu Yeyu Falü Daxue) to run training courses, and in 1988 the SPC, together with the State Education Commission, created the China Senior Judges Training Center (Zhongguo Gaoji Faguan Peixun Zhongxin) to conduct short full-time courses for judges. In 1997 the SPC established the National Judges Institute (Guojia Faguan Xueyuan) to be in charge of judges' training. ${ }^{48}$

The courts do not routinely publish statistics on the education of judges, and the available statistics are scattered. ${ }^{49}$ The numbers on judicial education that do exist, like the numbers on judicial personnel, are bedeviled by the use of categories that are not relevant or clear. For example, Junru Zhao $(1999,6)$ states that as of 1995,70 percent of judges had at least a junior college-level education, although not necessarily in law. ${ }^{50}$ The China Law Yearbook puts the proportion at 80 percent as of the end of 1997 (Falï Nianjian I998, 7I). ${ }^{51}$ If one thinks that a four-year undergraduate degree in law is an important qualification for judges, then this is not a helpful statistic. Yet the "junior college or above" (dazhuan yishang) category is the one most frequently used. ${ }^{52}$ Statistics for LL.B.s are hard to come by. Weili Zhang (I997) states that of 250,000 court cadres in $1997,5.6$ percent-approximately I 4,000 - held bachelor's degrees in any subject, and only 0.25 percent, or 625 , held postgraduate degrees in any subject. ${ }^{53}$ Xiaobin Li $(1998,52)$, in his study of nine basic-level courts, found that only 3 percent of the judges had proper LL.B. degrees; a full 45 percent did not have even the equivalent of a junior college-level education in any field. These numbers are roughly in line with the estimate of a group of law professors that fewer than ro percent of judges had proper LL.B. degrees (Interview 200r).

If we could get reliable numbers on LL.B. degrees, it is still not clear what they would tell us: an "LL.B." degree could come from a correspondence school, an institution with just provincial, not national, accreditation, or a university that established its law department solely to meet market demand and staffed it entirely with recycled faculty from the moribund Department of Marxist-Leninist Philosophy (Interview 200I).

Even if we could make definitive judgments about the educational level of judges using available numbers or numbers obtained through research, it remains to be seen whether the educational level of judges is something worth knowing. The first problem with these numbers is common to any set of national statistics in China: they are bound to obscure important regional differences. Knowledge that might be very important in Shanghaia judge's ability to understand complex corporate finance issues, for example - might be trivial in Qinghai. China is such a large and diverse country that any generalizations on the basis of national statistics must be made with care because they may not reflect the reality in another part of the country.

The second problem is that given the judicial environment in China, we must question the assumption that these statistics are worth knowing - that more education makes better judges. If we think of judges as officials whose job it is to extend state power into the countryside, where the great majority of China's population still resides, it is plausible to suppose that the skills acquired in an urban law faculty may not be those best suited to the task. Indeed, the much-criticized practice of assigning demobilized army officers to the courts as judges begins to seem more reasonable (see Clarke I996, 10). In short, an assessment of the qualifications of judges invariably involves an assumption about what judges ought to be qualified to do. It is crucial to justify that assumption.

The third problem is that a judge's education may contribute very little to a court's decision making. As one law professor stated (Interview 200r), there are many outside influences on a judge; to get ahead in the court world, judges may have to give up what they have learned. This, of course, could be true in many systems. The point is simply that one must be alert to the social and political environment in which judges operate before assigning particular significance to this or any other set of facts.

Finances. Again, given the bureaucratic nature of the courts in China, an important consideration - and one that is quantifiable - is funding. There are at least three subjects of interest here: how courts are funded, how they spend their funds, and the incentives facing courts and judges.

We know little about any of these subjects. ${ }^{54}$ Of course, the funding the government allocates to the courts in comparison to other institutions might indicate the relative importance of the courts. But it does not speak to the funds available to the courts from all sources: a great deal of the courts' income comes not from budget allocations but from litigation fees. ${ }^{55}$

How courts spend their discretionary funds is a key indicator of what their leading personnel think is important, a better indicator of court priorities than the numbers of cases in various areas. Sheer numbers of cases alone may not be a reliable indicator of anything: courts and judges are rated for performance based on the number of cases processed, and so have an incentive to inflate those numbers. ${ }^{56}$ We could look at expenditures per chamber, but this might skew the statistics in favor of the chambers with greater ac- 
cess to litigation fees (for example, the civil chambers). Or we could look at the number of judges assigned to each chamber. This might be a good measure because the court president, who does the assigning, probably knows where judges are needed, whatever the nominal number of cases. But here, again, we have the problem of deciding who counts as a judge.

One of the most interesting subjects for research - to the best of my knowledge, still terra incognita in terms of published systematic studies- has to do with the incentives facing individual judges. To understand judges' incentives is to understand a very important element in the functioning of the courts in China. For example, consider the current practice whereby lower courts, before they make a decision, communicate with their superior court to obtain that court's views on the matter in question. This practice, called qingshi ("asking for instructions") or shenpan huibao ("reporting during adjudication"), has been heavily criticized..$^{57}$ Concerns center around the legality of the practice-it has no basis in any laws or regulations governing court procedures-and its impact on appeals: the practice effectively strips losing parties of their right to appeal because the matter has already been judged by the superior court. The practice is unlikely to stop, however, as long as being reversed on appeal is considered in all cases to be a failure at work and is punished as such..$^{58}$ In one court, if just two of a judge's cases are reversed on appeal or sent back for retrial in a year, the judge cannot be named as "advanced" that year (Interview 200I) ${ }^{59}$ In another court, the responsible judge is fined so yuan for each case reversed on appeal and roo yuan for each case sent back for retrial (Zhu 1999, 51) ${ }^{60}$ With incentives like these, it is hardly surprising that judges want to know what the superior court thinks before they make their decision. According to Yuan and Qi (1996, 99), in the first half of 1996 the Nanjing Intermediate-Level People's Court made judgments in a total of I, SI 4 cases; of those, in just 2 cases was the judgment changed on appeal or the case sent back for retrial.

Caseloads. National case statistics are easy to come by: they are published annually in the China Law Yearbook and in other places. But what can they tell us? A number of features of the way Chinese courts operate make it risky to draw conclusions from caseload numbers. ${ }^{6}$

First, the courts and their personnel generally are rated on the basis of objective numbers, not on the basis of subjective evaluations of the quality of their work. As a result, courts and judges do what they can to maximize the numbers for which they are rewarded and to minimize the numbers for which they are punished. Because one important index of accomplishment is the number of cases processed, courts and judges have an incentive to maximize the number of cases they take on and see through to final judgment and execution. To raise their case count, then, judges may insist that a single case brought by several plaintiffs be disaggregated into several complaints; after the petitions are accepted, the cases are consolidated again for trial (Interview 200I)

Second, the courts historically have relied on litigation fees for the bulk of their funding. ${ }^{62}$ This creates an incentive, given competing demands on time and resources, to concentrate on cases that bring in high fees and to give short shrift to those that do not. Where a case involves an object of commercial value, courts can set litigation fees at a percentage of the amount in controversy. Therefore, the courts naturally favor.commercial cases over, say, administrative cases or divorce cases. As a result, an observed increase in the proportion of commercial cases on a court's docket may mean that commercial disputes have become more prevalent. It may also mean simply that the government has cut the court's budget, forcing the court to earn more money through litigation fees. ${ }^{63}$

Case statistics can also be used in other ways. Suli Zhu (Su 2000a), for example, has attempted to show that the popular image of BLPC judges as ignorant and overbearing ex-army officers is incorrect, and that such judges are in fact doing a reasonably good job. He supports his argument by pointing to a decline in appeals from first-instance judgments over time, a trend that he interprets as reflecting an increase in the quality of the courts. But the conclusion depends crucially on the premise that failure to appeal indicates satisfaction with the fairness and correctness of the judgment (I2) - a premise whose soundness seems open to question. We can imagine many reasons for failing to appeal a judgment that are not related to a belief that the judgment is fair, among them the cost and benefits of appeal and the likelihood of success (see Yi 2000, 75I).

People's Tribunals. In any general study of the court system in China, the chief focus must be on the Basic-Level People's Courts. These are the courts with which the vast majority of complainants have contact. And in studying the BLPCs, it is essential to look at the People's Tribunals (PTs; renmin fating).

PT's are branches of BLPCs staffed by BLPC judges. With the approval of the provincial-level court for the jurisdiction, a BLPC may establish a PT in an outlying area to make it easier for parties from that area to come to court. ${ }^{64}$ At present, PTs can hear civil cases, certain minor criminal cases, and, if the BLPC so allows, commercial cases. Presumably, the BLPC could take a case out of the hands of a PT and hear the case at its own seat if it considered the case to be sufficiently important. The decision of a PT is the decision of the BLPC: appeals are to the court above the BLPC, not to the BLPC. ${ }^{65}$

In the I99os, PTs seemed to fall somewhat out of favor with policymakers, and their number dropped significantly-from about 18,500 in I99I 
(Clarke 1996, 7-8) to about 12,000 at the end of 1999 (Falü Nianjian 2000, I35). A r 999 court reform plan called for all PTs in municipal districts ( $q u$ ) to be eliminated and for others in economically developed areas to be merged. ${ }^{66}$

Despite the decline in their numbers, PTs remain significant. Of the 5.7 million first-instance cases adjudicated by the courts in I999, most of which would have been heard by BLPCs, some 2 million were heard by PTs (Falü Nianjian 2000, I33). Xiaobin Li (1998, 52) reported that the nine BLPCs he studied had established sixty-five PTs. The tribunals were staffed by 37 percent of the BLPCs' total judicial personnel, even though they heard 67 percent of the cases. According to Zhang and $\mathrm{Wu}(2000,70)$, there were 75,553 cadres and police (the broadest category-ganjing) in PTs in 1998, of a total of 280,000 in all courts (see Table 5.I). Clearly the PT is a significant institution.

\section{Conclusion}

One of the primary obstacles to the study of China's judicial system is the fact that the government treats so much of the relevant information as sensitive. Consequently, even seemingly innocuous information - such as the number of judges, their education, and their pay structure-can be very difficult to obtain. And the problem affects Chinese and non-Chinese scholars alike: all are usually relegated to essentially the same sources. Where Chinese scholars have an advantage, however, is in fieldwork in the judicial system. Chinese officials are far more willing to speak frankly to a fellow Chinese, particularly from a prestigious university, than to a foreign researcher. ${ }^{67}$ Fieldwork can yield interesting and original results, but unfortunately it typically does not yield representative statistics unless great care is taken in selecting the objects of study (Manion 1994).

One key to understanding China's legal institutions lies in knowing more about the people who staff them. Much could be learned from a study of the career path, education, and income of judges and procurators. Those data could also serve as a proxy for a measure of the social and political importance of courts: if they show that the courts increasingly are staffed by highstatus persons who have good alternative career opportunities, we would have evidence that their political status - and by extension, that of the courts -is rising.

Another promising area of research is the subject of judicial incentives. Where judicial independence enjoys significant protections - consider the federal judiciary in the United States, for example-decision making has proved difficult to model. ${ }^{68}$ But it may not be as difficult in China, where financial and other incentives within the courts are common. The difficulty here lies in the lack of uniformity in the courts, a problem that could be overcome by collecting data on a sufficiently large random sample.

An important finding here is that information about China's judicial system, even in the form of reliable and representative statistics, is not always what it seems. In other words, without a deeper understanding of the functioning of China's courts and other legal institutions, it is very easy to look for the wrong type of information and to misinterpret the information we have. Like the drunk in the joke who looked for his lost car keys under the streetlamp because the light was better there, we may be tempted to overvalue those elements of China's judicial system for which we have data simply because the data are available. Thus, a priority in an empirical research agenda at this stage of our understanding should be further study of the actual functioning of China's various legal institutions so that we have a better idea of what questions to ask.

\section{Notes}

I. The project's Web site address is www.gtz_commercial_laws.org.cn.

2. Stephenson (2000) is a fine study of U.S. government involvement in rule-oflaw and similar programs in China. Executive branch initiatives began in 1994 with President Clinton's announcement that the United States would sponsor programs to promote civil society, including the rule of law, in China. In 1996, the administration created the post of Special Coordinator for Global Rule of Law within the State Department, and followed that in 1999 with the creation of the post of Coordinator for China Rule of Law Programs. Nevertheless, strong congressional opposition to cooperative programs with the Chinese government meant that significant funding for China-related activities was not available. In October 2000, Congress finally authorized the Departments of Commerce, Labor, and State respectively to establish rule-of-law training programs in China (22 U.S.C. \$698I); and in the following month Congress authorized grants to nongovernmental organizations outside China involved in fostering democracy and the rule of law in China (Foreign Operations, Export Financing, and Related Programs Appropriations, 2001, Public Law 106-429, appendix A, $\$ \$ 26)$. Through the efforts of Senator Arlen Specter of Pennsylvania, \$1.75 million was granted to Temple Law School to support its LL.M. program in Beijing (Congressional Record [June 22, 2000], I46, $\$ 5621$ [statements of Senator Specter]); see also Lin (2001).

3. Wuhan University's Center for the Protection of the Rights of Disadvantaged Citizens was established in 1992 with financial support from the Ford Foundation (Liebman 1999). In June 2000, the foundation supported a ten-day workshop for twenty midlevel Chinese officials at Georgetown University Law Center. During the eighteen months following the workshop, the foundation sponsored a series of 
additional seminars in China on legal system changes implicit in WTO membership These in-China programs emphasized judicial review of administrative decision and the establishment of administrative hearing processes.

4. See generally Peerenboom (200ra), a study commissioned by the Ford Foundation.

5. The discussion here regarding the lack of data should be qualified by noting the recent appearance of a major two-volume collection of historical statistics on the courts in China, covering the half-century from 1949 through I998 (SPC Research Department 2000a, 2000b). Interestingly, although the volume covering civil law is available to the general public, the volume covering criminal law is for circulation among court personnel only (personal communication, Supreme People's Court Bookstore, Beijing).

6. Some of the results of this project have been published by Su (2000b) and Xiaoli Zhao (2000). Su Li is the nom de plume of Suli Zhu, the dean of Beijing University's Faculty of Law. (For consistency and ease of reference, all Chinese names in this chapter are written with the surname last.)

7. The occasional exception: tables showing numbers of procurators (see, e.g., Falü Nianjian 1998, table 6; and 2000, table 2) and their participation in training programs (see, e.g., Falii Nianjian I999, table I I; and 2000, table 3).

8. For general yearbooks, see, for example, the Yearbook of the People's Republic of China (Zhonghua Renmin Gongheguo Nianjian), the Statistical Yearbook of China (Zhongguo Tongji Nianjian), the Yearbook of China's Economy (Zhongguo Jingji Nianjian), and Social Statistics of China (Zhongguo Shehui Tongji Nianjian).

For examples of topical yearbooks, see the China Securities Industry Yearbook (Zhongguo Zhengquan Ye Nianjian), the China Yearbook on the Non-State-Owned Economy (Zhongguo Fei Guoyou Jingji Nianjian), the China Yearbook of Educational Statistics (Zhongguo Jiaoyu Tongji Nianjian), the similarly named China Yearbook of Statistics in Education (Zhongguo Jiaoyu Shiye Tongji Nianjian), and the China Labor Statistics Yearbook (Zhongguo Laodong Tongii Nianjian). The last contains statistics on labor arbitration cases, for example.

The Beijing Yearbook (Beijing Nianjian) and the Guangdong Yearbook (Guangdong Nianjian) are local yearbooks. On the whole, local yearbooks are not as helpful as general or topical yearbooks, and their legal coverage tends to focus on criminal matters.

9. In many cases, the authors are simply repeating an unattributed number they picked up somewhere else, a number that with frequent repetition acquires the patina of authority.

IO. In Weifang He's (1998) study of the Chinese judiciary, he attempts to derive reliable numbers for judicial personnel by piecing together bits and pieces of information from journal articles, leaders' speeches, and newspaper reports.

II. See, for example, Pei (1997), who uses percentages derived from an unrepresentative sample of administrative cases to describe general types of plaintiffs and remedies. Manion (1994) argues that under appropriate conditions, valid inferences about the relationships among variables can be drawn from unrepresentative samples.
12. Manion (I994), for example, speaks to the problem in China: "For most researchers, obtaining a nation-wide probability sample of the Chinese population is both impossible and impractical" (74I).

13. See, for example, Katō and Xiao (1999) and Potter (1994). Methodological insight might also be gained by examining studies of legal culture in other culturally Chinese jurisdictions, such as Hong Kong (Hsu 1992) and Taiwan (Potter 1995).

I4. O'Brien (I996), for example, writes about the strategic use by rural protesters of laws and regulations but never once mentions the courts. And that omission is neither an oversight nor a mistake. It is simply an accurate reflection of the usefulness of the courts in the eyes of rural protesters.

I5. The reference is to Dworkin's "The courts are the capitals of law's empire" (1986, 407).

6. Jianchayuan also is translated as "procuratorate."

17. For more on the procuracy, see Chen (1992, I24-27); Wang and Mo (I999, 58-60); and especially Fu (2001).

I8. Notably Ginsburgs and Stahnke (1964, 1965, 1968); Hsia and Haun (1978); and, more recently, Fu (200r).

I9. I say "may" precisely because we cannot conclude one way or the other before the necessary research has been undertaken.

20. It is not always clear whether primary responsibility for legislative drafting should lie with the State Council and its Legal Affairs Office or with the NPC and its Legislative Affairs Commission (Fazhi Gongzuo Weiyuanhui). At times a political struggle may be involved. The formal functions of the Legal Affairs Office are described in Wang and Mo (1999, 13-14). For the politics of lawmaking, see Tanner (1999), especially pages $46-47$.

21. According to Hongwei Shen, since the inception of the lawyer's examination in 1986 , more than I million people have applied to take the test; of those, 120,000 have passed and obtained lawyer qualifications. However, he states that only half of those $(60,000)$ currently work as lawyers. Shen cites no source for his statistics.

22. On the coercive aspects of mediation, see generally Clarke (x99I, 292-94). On mediation in general, see Lubman (1999, 40-70, 217-49); and Tang (1994)

23. The picture here is actually more complex than can be described in a short paragraph, and it is constantly changing.

24. In China International Engineering Consultancy Company v. Lido Hotel Beijing (I992), a Chinese court had refused to enforce an award rendered by the China International Economic and Trade Arbitration Commission (CIETAC) despite the fact that CIETAC and both parties agreed that CIETAC had jurisdiction. The court found that CIETAC could not hear cases between two domestic enterprises. CIETAC subsequently amended its rules to give itself that jurisdiction. If CIETAC was a private institution, it would not have been able to bootstrap its own authority by simply changing or clarifying a rule. In a personal communication to the author, a senior CIETAC official stated that the rule change had been approved by the Legislative Affairs Commission of the NPC, the State Council's Legal System Bureau, and the Supreme People's Court. 
25. See, for example, the rules of the Beijing Arbitration Commission, discussed in Clarke and Davis (1999)

26. Commission staff can be considered quasi-government employees.

27. For more on arbitration in China, see generally Håkansson (I999) and Sheng Chang Wang (1996)

28. For a useful comparative perspective that examines the many ways in which U.S. judges promote settlements, see Galanter (1988) and Galanter and Cahill (I994).

29. On courts in general, see Finder (200r).

30. Article III of the U.S. Constitution limits the judicial power to "Cases" and "Controversies." In a well-known letter to President George Washington in I793, the justices of the Supreme Court declined to issue an advisory opinion (an opinion not related to a specific case). For a study of the advisory role of courts in the early Republic, see Jay (1997).

31. See generally Xiaoli Zhao (2000, 64).

32. See, for example, Waltman (1988), who states that "courts, more than any other public body, are for the purpose of making decisions" (4), and Shetreet (I988), who declares that "the primary function of courts within tion of disputes" (468).

33. The yamen was the office of the district magistrate, the chief official in charge of a county in imperial China. The district magistrate's duties included adjudication, to be sure, but only as one of many. See generally Watt (1972) and Stephens (1992, $40-43$ ).

34. The extent to which this ideology has carried the day is a matter of dispute. Some observers believe that the ideology of legality has won a complete victory, in the sense that the government now considers it necessary at least to pay lip-service to it and to hide or deny perceived deviations from it. These arguments are not with out force. But even if we accept the proposition that what people say is more important than what they do, those who proclaim the victory of the ideology of legality overlook the vast amount of extralegal activity in China carried on quite openly because its extralegal quality is not even perceived. Certain aspects of rural land use, for example, are to this day governed by Party policy, not the (apparently) applicable law. The strength of the Party is also visible in the detention and investigatory powers of Communist Party Discipline Inspection Commissions, powers that cannot be chailenged via any legal means, although they clearly are not grounded in the law. See generally Fu (200I). It is presumably pursuant to these powers that former premier Ziyang Zhao was held in I989 and remains held today; thers that forhas never attempted to justify his detention by reference to legal or administrative proceedings.

35. Courts in China have not been powerful institutions. During the era of the planned economy, they had little role to play in resolving disputes among major economic actors. Their primary activity, outside of their role in the criminal process, was adjudicating minor civil disputes between individuals.

It is not my claim that Chinese courts should be considered important legal institutions; it is my claim that people who matter in China believe the courts as they exist in China today are the courts called for in the ideology of legality, and that they are therefore important.

36. I thank Teemu Ruskola for bringing this quotation to my attention.

37. The term "cadre" refers to a person with special official status within the Chinese political system.

38. The CLY has not provided tables about court personnel since its I988 edition, but certain statistics can be found here and there. For example, a brief article by the Supreme People's Court in the 1998 edition states that there were more than 280,000 people working in the courts at the end of 1997 (Falï Nianjian 1998, $7 \mathrm{I}$ ). That figure evidently includes just about everyone, because the numbers of judges, clerks, and court police are noted separately at $170,000,50,000$, and 2,000 respectively.

39. For some reason, personnel statistics on the procuracy are not considered so sensitive; or perhaps the procuracy is simply better at collecting numbers. According to Tan (200I), in 1997 there were 160,000 people who might be called "pure procurators," in the sense that the numbers do not include clerks, judicial police, or other cadres. Tan then asserts that there were a total of 180,000 cadres in the same year - in other words, that there were 20,000 people with cadre status working in procuratorial offices other than those with the rank of procurator. Field research is needed to find out exactly what procurators do before any significance can be assigned to these numbers.

40. More numbers from 1979 through 1995 , and their sources, can be found in Weifang $\mathrm{He}\left(1998, \mathrm{r}_{3}\right)$.

4I. For an interesting news report along these lines, see Haijian He (1993), who reports that he could not find anyone he was looking for at a local court because they had all been dispatched to the streets to tear down unsightly advertisements touting cures for sexually transmitted diseases.

42. People's assessors are laypeople brought in to hear cases alongside regular judges. Unlike jurors in a common law trial, whose function is supposed to be limited to fact-finding, people's assessors function in theory like judges and have an equal vote. It is generally agreed among scholars that people's assessors in practice have little real power.

43. "An investigation of reality shows that the system of people's assessors has already been completely abandoned in many courts, and in fact exists in name only. This is the reality of the people's assessor system; it is an undeniable fact" (Jungui Shen 1999, I 5 ). Several articles on the system of people's assessors appear on page 4 of the June S, I999, issue of the Legal System Daily (Fazhi Ribao).

44. Like judges, assessors apparently are being used-inappropriately - to enforce judgments (Interview 2001). People's assessors have the same rights and powers as judges hearing a case, except that they always must hear cases as part of a panel that includes a judge. Judges can hear cases on their own when a summary procedure is called for.

45. Liming Wang $(2000,398)$, for example, states that in 1997 there were 250,000 judges. But the source he cites-Hao Li $(1998,84)$ - clearly states that the number 
applies to cadres (ganbu), a much broader category that includes clerks, court police, drivers, and other nonadjudicatory personnel. The most careless Western scholar would be unlikely to confuse a category that included bailiffs with a category that included only judges; that Wang, who is by no means a careless scholar, could do so is highly suggestive of the categories that really count in the Chinese legal system. 46. "Ke" usually is translated as "section." For our purposes it is important to know that ke-level cadres are very low on the bureaucratic totem pole, equivalent to the rank held by a township (xiang) head or the head of an administrative department of the county (xian) government. It is one rank below that held by a county head or deputy head $(c h u)$. Because there is typically one BLPC per county, the judges' lower rank indicates very clearly their relationship to the government organs at the same administrative level.

47. But see the discussion of court finances below.

48. For more on judges' training, see Liming Wang (2000, 447-49).

49. The SPC's annual work reports, for example, typically do not mention judges' educational levels, although they may note the existence of training programs. The China Yearbook of Education Statistics (Zhongguo Jiaoyu Shiye Tongji Nianjian) also says nothing about the educational levels of judicial officials, but it does have figures for those currently involved in legal education. Even those figures, however, are difficult to interpret because in many cases the relevant statistics reflect enrollment only in political-legal schools and institutes (zheng-fa yuan-xiao); they do not consider students in law faculties in comprehensive universities and colleges. Still, Weifang He (1998) makes a valiant attempt to collect statistics on judicial education from these and other sources.

50. Zhao attributes this information to the SPC but does not cite a specific source.

5r. Again, we do not know if by "judges" the author means all cadres. (approximately 270,000 people) or only those formally entitled to hear and decide cases (approximately i 70,000 people).

52. Even this category is not especially helpful. Court officials generally obtain junior college degrees or their equivalent in one of three ways: (x) after-hours training programs arranged by the court in which they work; (2) adult education correspondence courses with regular universities; and (3) self-study followed by an examination. According to Cheng (200r, I79), the prevalence of corruption in the adult education industry makes even these numbers highly suspect as an indicator of actual education received. Moreover, the numbers apply to those who passed the relevant course even though they may not have gone beyond middle school in their regular education.

53. Figures for the procuracy are even lower: of 180,000 cadres in the procuracy, only 4 percent had an undergraduate degree and only o.Is percent had a postgraduate degree (Weili Zhang I997).

54. On the question of how courts are funded, a recent study by Xue and Zhang (200I) of the courts in Jiangxi Province is the most detailed and revealing I have seen. 55. In January 2002, the Ministry of Finance and the People's Bank of China issued a joint notice (MOF and PBOC 2002) furthering the government's stated pol- icy of separating state agency revenues from expenditures (shou zhi liang-tiao xian). The notice provides that all fees received by the SPC and several other central government bodies are to be deemed central government financial revenues; fees received by local courts and other local government bodies are to be deemed revenues of that body's supervisory department (zhuguan bumen), where applicable regulations so provide, and general revenues of the local government where they do not. Because local courts do not have an official supervisory department, that presumably means their fees will be included in local government revenues. The notice does not, however, state a corollary rule: that budgetary allocations to courts may not be made dependent on their fee collections. Without such a corollary rule, the provisions of the notice may have little effect on the institutional incentives facing courts.

56. See the section on caseloads that follows.

57. See, for example, Zhuqiao Zhou (I99I) and Liming Wang (2000, 439); but see Zhou and Liu (1993), who support the practice.

58. The issue of punishing judges for "wrong" decisions is discussed by Liming Wang (2000, 437-4I). Many, including Liming Wang, support the practice of punishing judges for wrong decisions on the grounds that judicial corruption has made it necessary; others, among them Chenguang Wang (I998), oppose it on the grounds that legal indeterminacy makes it impossible to speak of a single right answer to legal questions.

59. Being named as advanced is an important part of an official's professional record and affects the individual's chance for promotion.

6o. The monthly salary of a BLPC judge in Beijing might be in the neighborhood of 3,000 yuan.

$6 x$. For an examination of caseloads, see Chapter 6 in this volume

62. Change is in the wind, though. See note 55 .

63. Weng (1997, 28) describes how in 1997 his local court established a formal standard for fee collection (with no legal basis): in addition to regular fees, it began collecting "litigation activity fees" (susong huodong fei) of up to-in fact, alwaysso percent of the amount of the regular fees. The law professors I interviewed in 200 I told of cases in which courts had collected money owed by a defendant to a plaintiff and held on to it for an extended period, lending it out at interest before passing it on to the plaintiff. One professor referred to the courts as "People's Courts, Inc." (Renmin Fayuan Youxian Gongsi).

64. On PTs in general, see Clarke $(1996,7)$. The most recent rules governing PTs were issued by the SPC in August 1999: "Guanyu Renmin Fating Ruogan Wenti de Guiding" (Rules on Several Issues Relating to People's Tribunals). Relevant parts of the rules are discussed in the text.

65. "Zhonghua Renmin Gongheguo Renmin Fayuan Zuzhi Fa" (Organic Law of the People's Courts of the People's Republic of China), Article 20.

66. Supreme People's Court, "Renmin Fayuan Wu-Nian Gaige Gangyao" (Outline of Reform of People's Courts over Five Years), October 20, I999.

67. It is possible to overstate this advantage. In his study of People's Tribunals, Xiaoli Zhao of Beijing University's Faculty of Law found that access-even for Chinese academic from a prestigious institution-still depended on the existence of 
a personal connection between court officials and the researcher or a fellow researcher (personal communication 200I).

68. For an interesting attempt, see Bainbridge (200I).

\section{References}

Arnold, Thurman W. 1935. The symbols of government. New Haven: Yale University Press.

Bainbridge, Stephen M. 200I. How do judges maximize? (The same way everybody else does-boundedly): Rules of thumb in securities fraud opinions. Abstract no. 28326r. Available at www.ssrn.com.

Burke, Edmund. $1790 / 1982$. Reflections on the revolution in France. New York: Penguin. (Originally published in 1790 .)

Chen, Albert H. Y. 1992. An introduction to the legal system of the People's Republic of China. Hong Kong: Butterworths Asia.

Cheng, Zhuru. 200I. Sifa gaige yu zhengzhi fazhan (Judicial reform and political development). Beijing: Zhongguo Shehui Kexue Chubanshe.

Clarke, Donald C. 1991. Dispute resolution in China. Journal of Chinese Law 5, no. 2 : $245-96$.

- I996. Power and politics in the Chinese court system: The enforcement of civil judgments. Columbia Journal of Asian Law Io, no. I: I-125.

Clarke, Donald C., and Angela H. Davis. r999. Dispute resolution in China: The arbitration option. In China 200o: Emerging investment, funding and advisory opportunities for a new China (I $5 \mathrm{I}-62$ ), edited by Asia Law and Practice. Hong Kong: Euromoney.

Cui, Li, and Liangqing Yang. 200r. Jujiao shiji sifa zhuti: Gongzheng yu xiaolü (Focusing on the judicial theme of the century: Justice and efficiency). Zhongguo Qingnian Bao (China Youth News), December 17, Internet ed. Available at www .cyd.com.cn (January I I, 2002).

DeLisle, Jacques. I999. Lex Americana? United States legal assistance, American legal models, and legal change in the post-communist world and beyond. University of Pennsylvania Journal of International Economic Law 20, no. 2: 179-308.

Dworkin, Ronald. 1986. Law's empire. Cambridge, Mass.: Belknap Press.

Falü Nianjian (Law Yearbook). 1988, I998-2000. Beijing: Falü Nianjian Chubanshe.

Finder, Susan. 200I. Court system. In Doing business in China (I-2.I.I-I.36), edited by Freshfields. Huntington, N.Y.: Juris.

Fu, Hualing. 200I. Procuracy. In Doing business in China (I-2.2.x-2.17), edited by Freshfields. Huntington, N.Y.: Juris.

Galanter, Marc. I988. “. . A settlement judge, not a trial judge”: Judicial mediation in the United States. In The role of courts in society $(295-318)$, edited by Shimon Shetreet. Dordrecht, The Netherlands: Martinus Nijhoff.

Galanter, Marc, and Mia Cahill. I994. Most cases settle: Judicial promotion and regulation of settlement. Stanford Law Review 46, no. 6: I339-9I.

Ginsburgs, George, and Arthur A. Stahnke. I964. The genesis of the People's Pro- curatorate in Communist China. China Quarterly, no. 20 (October-December): I-37.

- 1965. The People's Procuratorate in Communist China: The period of maturation, I95I-I954. China Quarterly, no. 24 (October-December): 53-9I. - 1968. The People's Procuratorate in Communist China: The institution ascendant. China Quarterly, no. 34 (April-June): 82-I32.

$\mathrm{Gu}$, Peidong. I999. Zhongguo lüshi zhidu de lilun jianshi yu shizheng fenxi (xia) (A theoretical examination and positivist analysis of China's lawyer system [part 3]). Zhongguo Lüshi, no. I2: SI-52.

Håkansson, Cecelia. I999. Commercial arbitration under Chinese law. Uppsala, Sweden: Iustus Förlag.

He, Haijian. I993. Faguan, xingbing guanggao ji qita (Judges, venereal disease advertisements, and other matters). Renmin Fayuan Bao (People's Court News), October 8,2 .

He, Jiahong. I999. Peishen zhidu gaige duanxiang (Thoughts on the reform of the system of assessors). Zhongguo Lüshi, no. 4: I2-I3.

He, Weifang. 1998. Tongguo sifa shixian shehui zhengyi (Achieving social justice through judicature). In Sifa de linian $y u$ zhidu (The ideals and institutions of $j u$ dicature) $(\mathrm{I}-84)$, edited by Weifang He. Beijing: Zhongguo Zheng-Fa Daxue Chubanshe.

Hsia, Tao-t'ai, and Kathryn A. Haun. 1978. The re-emergence of the procuratorial system in the People's Republic of China. Washington, D.C.: Library of Congress Law Library.

Hsu, Berry. 1992. The common law in Chinese context. Hong Kong: Hong Kong University Press.

Interview with members of the Beijing University Faculty of Law. 200I. March.

Jay, Stewart. I997. Most humble servants: The advisory role of early judges. New Haven: Yale University Press.

Jiang, Ming'an, ed. 1998. Zhongguo xingzheng fazhi fazhan jincheng diaocha baogao (Investigation report on the development of China's administrative rule of law). Beijing: Falï Chubanshe.

Katō, Masanobu, and Xianfu Xiao. 1999. "Chũgokujin no hō ishiki" chōsa kihon hōkoku sho (Basic investigation report on "the legal consciousness of the Chinese"). Hōsei Ronshū, no. I2: I-74.

$\mathrm{Li}$, Hao. I998. Faguan suzhi yu minshi susong moshi de xuanze (The quality of judges and the choice of model for civil litigation). Faxue Yanjiu (Research in Law), no. 3 : $80-88$.

$\mathrm{Li}$, Xiaobin. 1998. Shenpan xiaolü ruhe neng you da fudu tigao (How to greatly improve the efficiency of adjudication). Faxue (Jurisprudence), no. 10: $52-54$

Liebman, Benjamin L. 1999. Legal aid and public interest law in China. Texas International Law Journal 34, no. 2: $211-86$.

Lin, Jennifer. $200 \mathrm{I}$. Temple to use grant to expand law program in China. Philadelphia Inquirer, October 3 , Internet ed.

Lubman, Stanley. I999. Bird in a cage: Legal reform in China after Mao. Stanford, Calif: Stanford University Press. 
Manion, Melanie. 1994. Survey research in the study of contemporary China: Learning from local samples. China Quarterly, no. 139 (September): 74I-65.

Ministry of Finance (MOF) and People's Bank of China (PBOC). 2002. Guanyu gong'an deng bumen shoufei shouru naru yusuan guanli de tongzhi (Notice on the bringing under budgetary administration of revenues from fees received by public security and other departments). (Effective January $\mathrm{I}$. )

O'Brien, Kevin. r996. Rightful resistance. World Politics 49: $3 \mathrm{I}-55$.

Peerenboom, Randall, 200ra. The Ford Foundation and legal reform in China. Unpublished report on file with the author.

- 20orb. Seek truth from facts: An empirical study of the enforcement of arbitral awards in the People's Republic of China. American Journal of Comparative Law 49, no. 2: 249-327.

Pei, Minxin. 1997. Citizens v. mandarins: Administrative litigation in China. China Quarterly, no. IS2 (December): 832-62.

Potter, Pitman B. 1994. Socialist legality and legal culture in Shanghai: A survey of the getihu. Canadian Journal of Law \& Society 9, no. 2: 4I-72

-. I995. Doctrinal norms and popular attitudes concerning civil law relationships in Taiwan. UCLA Pacific Basin Law Journal I3, no. 2: 265-92.

Shen, Hongwei. 200o. Lun woguo lüshi zige kaoshi zhidu (On China's system of examinations for lawyer qualifications). Hebei Faxue (Hebei Jurisprudence), no. $x$ :

Shen, Jungui. I999. Dui woguo peishenzhi de foudingxing sikao (Rejectionist thoughts about China's system of assessors). Zhongguo Lüshi (The Chinese Lawyer) no. 4: I4-I5.

Shetreet, Shimon. x988. Judging in society: The changing role of courts. In The role of courts in society $(467-85)$, edited by Shimon Shetreet. Dordrecht, The Netherlands: Martinus Nijhoff.

Stephens, Thomas B. I992. Order and discipline in China: The Shanghai Mixed Court, 1911-27. Seattle: University of Washington Press.

Stephenson, Matthew C. 2000. A Trojan horse behind Chinese walls? Problems and prospects of U.S.-sponsored "rule of law" reform projects in the People's Republic of China. UCLA Pacific Basin Law Journal i 8, no. i: 64-97.

$\mathrm{Su}, \mathrm{Li}$. 2000a. Jiceng faguan de sifa suzhi (The judicial qualifications of basic-level judges). Faxue (Jurisprudence), no. 3:8-16.

-. 2000 b. Song fa xia xiang (Bringing law to the countryside). Beijing: Zhongguo Zheng-Fa Daxue Chubanshe.

Supreme People's Court (SPC) Research Department, ed. 2000a. Quanguo Renmin Fayuan sifa tongji lishi ziliao huibian, 1949-1998, minshi bufen (Collected historical judicial statistics relating to People's Courts nationwide, 1949-1998, civil part) Beijing: Renmin Fayuan Chubanshe.

200ob. Quanguo Renmin Fayuan sifa tongji lishi ziliao huibian, 1949-1998, xingshi bufen (Collected historical judicial statistics relating to People's Courts nationwide, 1949-1998, criminal part). Beijing: Renmin Fayuan Chubanshe.

Tan, Shigui. 200r. Zhongguo sifa jigou gaige yanjiu (A study of the reform of China's judicial structure). Jiancha Ribao (Procuratorate News), February is. Available at www.jcrb.com.cn/ournews/asp/readNews.asp?id=23578 (April I 3, 2001).
Tang, Jun. 1994. A historical, philosophical and legal analysis of Chinese mediation. Rovaniemi: University of Lapland.Press.

Tanner, Murray Scot. 1999. The politics of lawmaking in post-Mao China: Institutions, processes, and democratic prospects. Oxford, England: Clarendon Press.

U.S. Department of Justice, Bureau of Justice Statistics. n.d. The world factbook of criminal justice systems. Available at www.ojp.usdoj.gov/bjs/abstract/wfcj.htm (April I6, 200I).

Waltman, Jerold L. 1988. Introduction. In The political role of law courts in modern democracies, edited by J. L. Waltman and K. M. Holland. New York: St. Martin's Press.

Wang, Chenguang. I998. Ban'an xiaolü yu fayuan neibu yunxing tizhi de gaige (Case-handling efficiency and the reform of the internal operations of courts). Faxue (Jurisprudence), no. 10: 46-51

Wang, Guiguo, and John Mo, eds. 1999. Chinese law. Boston: Kluwer Law International.

Wang, Liming. 2000. Sifa gaige yanjiu (Studies on judicial reform). Beijing: Falü Chubanshe.

Wang, Sheng Chang. 1996. Resolving disputes in the PRC. Hong Kong: FT Law \& Tax Asia Pacific.

Watt, John R. I972. The district magistrate in late imperial China. New York: Columbia University Press.

Weng, Qibin. I 997. Fayuan luan shoufei: He shi guan zha (When will the gate be closed on the uncontrolled collection of fees by courts?). Zhongguo Lüshi (The Chinese Lawyer), no. I2: 28-29.

Xue, Jiangwu, and Yongling Zhang. 200I. Fayuan jingfei baozhang wenti de fenxi yu sikao (Analysis and thoughts about the issue of guaranteeing court funding). Renmin Sifa (People's Judicature), no. 8: 37-40.

$\mathrm{Yi}$, Yanyou. 2000 . Zouxiang duli yu gongzheng de sifa: Sifa gaige yanjiu shuping (Toward an independent and just judicature: A review of research in judicial reform). Zhong-Wai Faxue (Chinese and Foreign Jurisprudence), no. 6: 739-65.

Ying, Songnian, and Shuhong Yuan, eds. 2001. Zouxiang fazhi zhengfu (Toward a government of rule of law). Beijing: Falü Chubanshe.

Yuan, Shuhong, and Shuyu Qi. I996. Yi fa zhi guo de jubu shijian (zhi yi): Nanjing Shi yi fa zhi shi diaocha baogao [A partial putting into practice of (the doctrine of) ruling the country according to law (I): A report of an investigation into Nanjing Municipality's ruling the city according to law]. Zhongguo Faxue (Chinese Jurisprudence), no. 6: 96-108.

Zhang, Weili. 1997. Zhongguo xuyao dapi falü rencai (China needs a large cadre of legal talent). Fazhi Ribao (Legal System Daily), October 3, 3 .

Zhang, Wusheng, and Zeyong Wu. 2000. Sifa duli yu fayuan zuzhi jigou de tiaozheng (Judicial independence and the adjustment of the organizational structure of courts). Zhongguo Faxue (Chinese Jurisprudence), no. 2: 55-70.

Zhao, Junru. I999. Fayuan sifa tizhi xianzhuang ji gaige qianzhan (The current situation of the judicial system in courts and the outlook for reform). Xiandai Faxue (Modern Jurisprudence) 25, no. 5 (October): $3-7$.

Zhao, Xiaoli. 200o. Tongguo hetong de zhili (Governance through contract). Zhong- 
guo Shehui Kexue (Chinese Social Science), no. 2: 120-32. Reprinted in Min Shang Faxue (Civil and Commercial Jurisprudence), no. 6: 56-68

Zhou, Peimin, and Jilong Liu. I993. Fayuan shenpan huibao zhidu de ruogan wenti (Several issues in the system of courts reporting during adjudication). Faxue $\mathrm{Za}$ zhi (Jurisprudence Magazine), no. 4: 24-25

Zhou, Zhuqiao. 1991. Qianxi shenpan huibao zhidu ji qi weihai (A brief discussion of the system of reporting during adjudication and its harms). Faxue Pinglun ( $J u-$ risprudence Review), no. 5: 70-72.

Zhu, Zhijun. 1999. Fayuan neibu qingshifeng bu ke zhang (The trend of seeking instructions within the court system must not be fostered). Faxue Zazhi (Jurisprudence Magazine), no. 4: 50-5I. 